\title{
Article
}

\section{Health visitor education for today's britain: Messages from a narrative review of the health visitor literature}

Malone, Mary, Whittaker, Karen, Cowley, Sarah, Ezhova, Ivanka and Maben, jill

Available at http://clok.uclan.ac.uk/14523/

Malone, Mary, Whittaker, Karen ORCID: 0000-0002-3493-9396, Cowley, Sarah, Ezhova, Ivanka and Maben, Jill (2016) Health visitor education for today's britain: Messages from a narrative review of the health visitor literature. Nurse Education Today, 44 . pp. 175-186. ISSN 0260-6917

It is advisable to refer to the publisher's version if you intend to cite from the work. http://dx.doi.org/10.1016/j.nedt.2016.04.007

For more information about UCLan's research in this area go to http://www.uclan.ac.uk/researchgroups/ and search for <name of research Group>.

For information about Research generally at UCLan please go to http://www.uclan.ac.uk/research/

All outputs in CLoK are protected by Intellectual Property Rights law, including Copyright law. Copyright, IPR and Moral Rights for the works on this site are retained by the individual authors and/or other copyright owners. Terms and conditions for use of this material are defined in the policies page.

\section{CLoK}

Central Lancashire online Knowledge www.clok.uclan.ac.uk

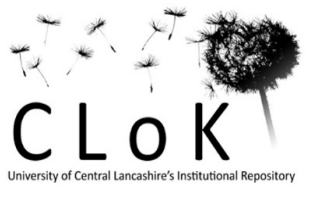




\section{Accepted Manuscript}

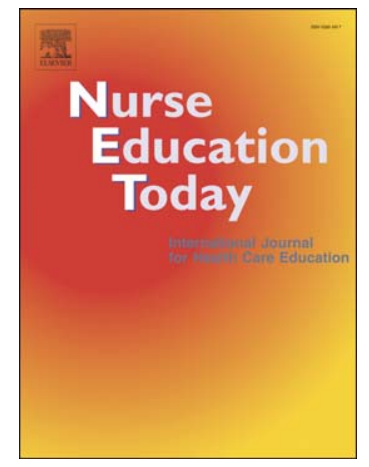

Health visitor education for today's britain: Messages from a narrative review of the health visitor literature

Mary Malone, Karen A. Whittaker, Sarah Cowley, Ivanka Ezhova, Jill Maben

PII: $\quad$ S0260-6917(16)30026-0

DOI: $\quad$ doi: $10.1016 /$ j.nedt.2016.04.007

Reference: $\quad$ YNEDT 3262

To appear in: $\quad$ Nurse Education Today

Received date: 28 June 2015

Revised date: 28 March 2016

Accepted date: $\quad 19$ April 2016

Please cite this article as: Malone, Mary, Whittaker, Karen A., Cowley, Sarah, Ezhova, Ivanka, Maben, Jill, Health visitor education for today's britain: Messages from a narrative review of the health visitor literature, Nurse Education Today (2016), doi: 10.1016/j.nedt.2016.04.007

This is a PDF file of an unedited manuscript that has been accepted for publication. As a service to our customers we are providing this early version of the manuscript. The manuscript will undergo copyediting, typesetting, and review of the resulting proof before it is published in its final form. Please note that during the production process errors may be discovered which could affect the content, and all legal disclaimers that apply to the journal pertain.

(C) 2016. This manuscript version is made available under the CC-BY-NC-ND 4.0 license http:// creativecommons.org/licenses/by-nc-nd/4.0/

This article may be used for non-commercial purposes in accordance with Elsevier Policy explained at: https://www.elsevier.com/about/company-information/policies/hosting 
Title: HEALTH VISITOR EDUCATION FOR TODAY'S BRITAIN: MESSAGES FROM A NARRATIVE REVIEW OF THE HEALTH VISITOR LITERATURE

\section{Authors:}

\section{Mary Malone, PhD, RHV, RN.}

King's College London. Dept of Child and Adolescent Nursing and the National Nursing Research Unit, Florence Nightingale Faculty of Nursing and Midwifery, James Clerk Maxwell Building, Waterloo Road, London SE1 8WA.

Tel: 02078483014

Fax:

Email: mary.malone@kcl.ac.uk (Corresponding author)

\section{Karen A Whittaker, PhD, RHV, RN}

University of Central Lancashire, College of

Health and Wellbeing.

Sarah Cowley, DBE, PhD, RHV, RN

King's College London. National Nursing Research Unit, Florence Nightingale Faculty of Nursing and Midwifery, Emeritus Professor

\section{Ivanka Ezhova, PhD}

King's College London

Jill Maben, PhD, RN

King's College London. National Nursing Research Unit, Florence Nightingale Faculty of Nursing and Midwifery,

\section{Acknowledgements}

The authors are grateful to Dr Sara Donetto for reviewing drafts of the manuscript.

\section{PRP disclaimer}

The NNRU health visitor research programme which this paper draws upon is an independent study commissioned and funded by the Policy Research Programme in the Department of Health. The views expressed are not necessarily those of the Department.

\section{Conflict of interest}

None 


\section{ABSTRACT (300 words)}

Objectives: This paper draws on a narrative review of the literature, commissioned to support the Health Visitor Implementation Plan (DH, 2011a), and aimed at identifying messages about the knowledge, skills and abilities needed by health visitors to work within the current system of health care provision.

Design: The scoping study and narrative review used three complementary approaches: a broad search, a structured search and a seminal paper search to identify empirical papers from the health visitor literature for review. The key inclusion criteria were messages of relevance for practice.

Data Sources: 378 papers were reviewed. These included empirical papers from the United Kingdom (UK) from 2004 - February 2012, older research identified in the seminal paper search and international literature from 2000- January 2016.

Review Methods: The review papers were read by members of the multi-disciplinary research team which included health visitor academics, social scientists and a clinical psychologist managed the international literature. Thematic content analysis was used to identify main messages. These were tabulated and shared between researchers in order to compare emergent findings and to confirm dominant themes.

Results: The analysis identified an 'orientation to practice' based on salutogenesis (health creation), human valuing (person-centred care) and viewing the person in situation (human ecology) as the aspirational core of health visitors' work. This was realised through home visiting, needs assessment and relationship formation at different levels of service provision. A wide range of knowledge, skills and abilities were required, including knowledge of health as a process and skills in engagement, building trust and making professional judgments. These are currently difficult to impart within a 45 week health visitor programme and are facilitated through ad hoc post registration education and training. The international literature reported both similarities and differences between the working practices of health visitors in the UK and public health nurses worldwide. Challenges related to the education of each were identified.

Conclusions: The breadth and scope of knowledge, skills and abilities required by health visitors makes a review of current educational provision desirable. Three potential models for health visitor education are described.

Keywords

- Health visitor practice

- Health visitor education

- Narrative review

- Knowledge, skills and abilities

- Public health nurse

- International 


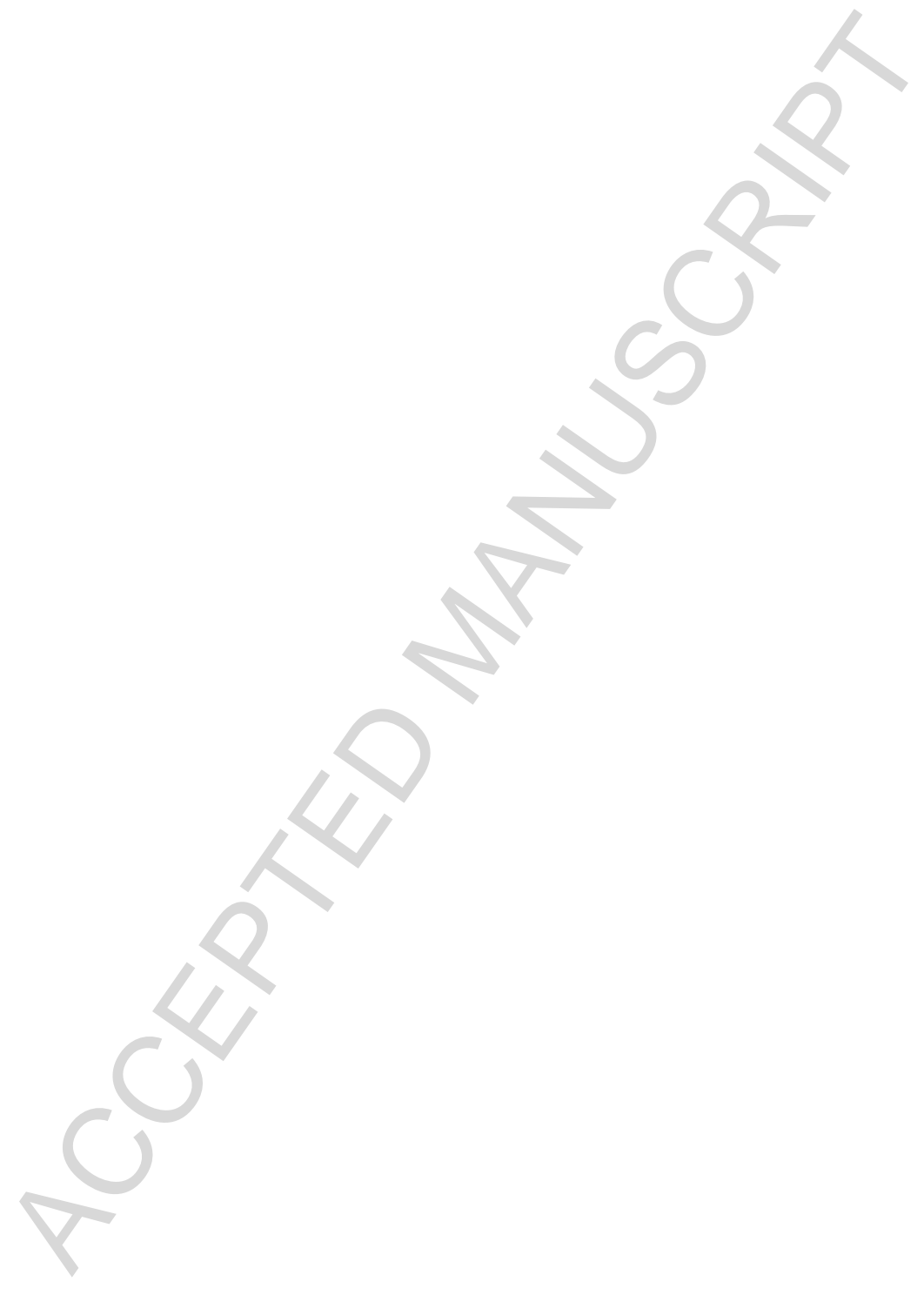




\section{INTRODUCTION}

Changing population profiles have led to international interest in the work of public health nurses and their potential to improve health outcomes (WHO, 2015). There is a huge diversity of practice roles and curricula for public health nurses within the European Union and around the world (European Commission, 2000; Cowan, Wilson-Barnett and Norman, 2006; Beck and Boulton, 2016; Asahara, Kobayashi and Ono, 2015).

In Ireland, Sweden, and Finland for example, public health nurses work not only with mothers and children but also with an aging population in need of continuing and complex care. Both the challenges and the innovative responses developed by public health nurses in these countries to delivering equitable care across such a diverse caseload have been well documented (McDonald et al., 2013; Hemingway, et al., 2012). In the United States of America, public health nurses have been reported to have various occupational classifications and educational backgrounds in health departments. They are essential to the delivery of a range of public health services, and are in possession of diverse competences related to clinical diagnostics, treatments, community health assessment, and policy development. In addition to this, public health nurses often intervene for vulnerable and underserved populations (Beck and Boulton, 2016). In Canada, each province has its regulations and legislation defining the services provided by health professionals and public health nurses mainly focus on visits to families and individuals in need of assistance with health-related issues. They collaborate with other divisions, government departments, and charitable organizations in promoting, disseminating, and implementing health activities in accordance with health education programs (Hemingway, et al., 2012).

In the United Kingdom the Five Year Forward View for the National Health Service (NHSE, 2014) and recommendations for nurse education (Willis, 2015) highlight the need for more nurses in community-based public health roles and for greater flexibility in nurse education to support this. In England, the Health Visitor Implementation Plan (HVIP) (DH, 2011a) led to one group of public health nurses, health visitors, becoming a particular focus of Government policy and investment. Health Visitors are qualified Specialist Community Public Health Nurses (SCPHNs) who promote population health by working with children and families to deliver the Healthy Child Programme (DH, 2009 a,b) within a service framework containing four levels of provision established in the HVIP (DH, 2011a). They are mandated to offer a minimum of five family contacts for child health and development reviews and there are six topics on which health visitors must intervene for family health gain (DH, 2014) (see figure 1).

In the European Union, the educational pre-requisites for qualification and subsequent practice as a public health nurse and health visitor vary from one country to another (European Commission, 2000; Cowan, Wilson-Barnett and Norman, 2006). In the United Kingdom, educational preparation for Health Visiting is open to registered nurses and midwives and contains 45 programmed weeks, divided equally between theory and teaching in practice (NMC, 2004). Current programmes of health visitor education are predicated on the Standards of Proficiency for SCPHN (the Standards) (NMC, 
2004) and approved by the Nursing and Midwifery Council (NMC, 2004). Since 2011, Government policy has also provided guidance on the educational content of health visitor programmes and teaching on specific topics, such as theories of community working, child development and maternal mental health (DH, 2011b).

This paper draws on the findings of a scoping study and narrative review of the health visitor literature (Cowley et al., 2013), to identify key educational messages for health visitors in Britain today. International literature has been drawn upon to complement findings from the original scoping study. The paper begins with a brief description of the review process. It moves on to consider the knowledge, skills, and abilities needed by health visitors and describes the challenges for health visitor education this involves internationally. The concluding section suggests that a radical rethink is needed and considers three potential models for future health visitor education in Britain.

\section{METHOD OF THE NARRATIVE REVIEW: AIM OF THE NARRATIVE REVIEW, THE REVIEW QUESTION AND THE AIM OF THIS PAPER}

The scoping study and narrative review that form the basis of this paper were commissioned to support the HVIP (DH, 2011a). They aimed to investigate the evidence for health visitor activities associated with each level of service provision (Figure 1) (Cowley et al., 2013), including evidence to explain the unique health visitor contribution to promoting child and family health. This paper draws upon evidence in the review to identify the knowledge, types of skills and abilities needed by health visitors internationally and considers how educators can best provide for these within programmes of health visitor education.

The review team included three academic health visitors, one nurse, two social scientists and a clinical psychologist who reviewed the international literature. The team used three main search strategies. First, papers were identified from a broad search of databases (e.g.Medline, Embase, British Nursing Index and Archive) using generic terms, like home visit*, which, after screening for messages of relevance to practice, yielded 593 papers of which 49 were reviewed in full. The terms "public health nurse" and/or "public nurse" were also used as was the term "health visitor". The latter is a professional title, mainly used in the United Kingdom. A major policy change in England (DH, 2004) established the current framework for child health services and so papers published after that date (2004) were identified as potentially most relevant to contemporary health visitor practice. Using the same databases and focusing on 15 topics of interest derived from the HCP (DH, 2009), a second search retrieved some 3000 papers, 218 of which were reviewed in full. In a third search health visitors in the research team reviewed a list of 272 papers generated from the initial broad search results, including papers published before 2004, secondary references and curricular materials from health visitor education programmes. This was to ensure inclusion of those papers known to be seminal to health visitor practice. This yielded 81 papers for review. Overall 348 papers were included 
in the scoping study and an additional thirty papers were reviewed to describe the international perspective.

Papers were categorised according to topic, reviewed by researchers who then tabulated and shared the content of their review. The methodological strength of each paper was reviewed and team members sought common themes between each topic group and across the topic areas. An in-depth thematic analysis was completed on a selection of the literature and this helped to clarify the theoretical and conceptual elements within health visiting practice.

All the papers reviewed were from empirical studies and two overarching themes were identified. The first theme identified and described a health visiting orientation to practice activated through three core health visitor practices: home visiting, relationship formation and health needs assessment, which research suggested worked in tandem with one another (Cowley et al., 2013). A second theme focused on the vast range of specific health visitor activities within each service level (see Figure 1). In this paper, core health visitor knowledge, skills and abilities are identified in theme 1 . Theme 2 illustrates the topic specific knowledge, skills and abilities health visitors need to work at each service level (Figure 1) (DH 2011a) with examples chosen for their relevance to child and family health promotion and for the particular educational messages they contain.

\section{THEME 1: HEALTH VISITORS' ORIENTATION TO PRACTICE AND THREE CORE HEALTH VISITOR PRACTICES: KNOWLEDGE, SKILLS AND ABILITIES IDENTIFIED IN THE NARRATIVE REVIEW}

The review identified a health visitor aspiration to make a unique contribution to child and family health through a particular way of working which we called an orientation to practice and key aspects of this are described here. The health visitor orientation to practice focuses on health creation (salutogenesis), rather than illness, recognises social, economic and emotional health determinants and the impact of these on human health behaviours (health ecology and person in-situation) and maintaining a non-judgmental positive regard for all persons (human valuing) irrespective of behavior (Cowley et al., 2013). Despite numerous variations in qualifications, competences, methods, and working practices of health visitors internationally, all the papers we reviewed expressed, either explicitly or implicitly, the knowledge, skills and abilities needed to work in this salutogenic way. For example, Cowley (1995a) identified health visitors' knowledge of health as a 'process', influenced by the environment and amenable to change, as central to this approach (Table 1). Subsequent papers (Cowley and Billings, 1999, Appleton and Cowley, 2008a) described health visitors using skills in engagement, engendering and building trust and making professional judgments to modify different environments including the social and emotional environment of the family home. Several papers but most notably Cowley (1991), Chalmers (1992), Turner et al, (2010) Appleton and Cowley (2008a) and Bryans et al. (2009) described how health visitors' ability to respect a family's priorities and to 
convey this respect to the family (human valuing) aimed to increase confidence in the ability to adopt health enhancing change. Table 1 illustrates the learning expressed as the range of knowledge, skills and abilities indicated within the review as necessary for the health visitor orientation to practice.

The health visitor orientation was manifest in three core practices of home visiting, relationship formation and health needs assessment and papers reviewed also indicated the knowledge, skills and abilities needed for these. Home visiting is the first of three core health visitor practices, and several papers described the particular knowledge, skills and abilities needed for this (Chalmers and Luker, 1991; Bryans, 2005 and Davis and Day, 2010). Communication skills (Chalmers and Luker, 1991) and skills and ability to build trust (Davis and Day, 2010) were especially emphasised. Bryans' (2005) study illustrated how mothers 'opened up' to health visitors combining their knowledge, skill and ability in communication and in building trust in a powerful 'person centredness' at the core of which was listening and attending to the mothers' agenda and conveying respect for this. In addition to this, Appleton and Cowley (2008a) demonstrated the health visiting need for different types of knowledge some of which was theory based (e.g. knowledge about maternal-infant interaction) whilst some related to the individual family in their unique situation.

The second core health visitor practice is relationship formation. Research spanning several decades identified the health visitors' ability to convey respect and genuine concern for the family's welfare as necessary pre-requisites for this (Chalmers and Luker, 1991; Cowley, 1995b; Bidmead, 2013). Other papers described compassion, containment and expressed sympathy as the basis of relationship formation (Cowley, 1995b; Whitehead and Douglas, 2005). Bidmead's (2013) qualitative research identified different stages of health visitor-client relationship formation and described the different attributes which underpinned each stage including valuing all individuals (human valuing), having a non-judgmental approach to the difficulties of family life, being reliable, giving sound advice, along with perseverance, or not giving up on families which was also described by Chalmers (1994).

The third core practice was health visitors' assessment of health needs. This was first described as a key principle of health visiting practice nearly four decades ago (Council for the Education and Training of Health Visitors 1977) and the ability to assess health needs remains an educational requirement for qualification (NMC 2004). Appleton and Cowley (2008a), amongst others, identified the different fields of knowledge, including child development, family functioning, ecology and influence of the environment needed by health visitors to assess the complexity of family life and stressed that this was particularly apparent when families were vulnerable and when children were at risk. Essential skills and attributes identified included the ability to make finely honed professional judgments about complex family situations and the flexibility to form and re-form those professional judgments in the face of changing family needs (Appleton and Cowley, 2008a).

Overall, the knowledge, skills and attributes necessary to deliver the core practices of health visiting appear intertwined in the research literature and in practice. They mirror core values such as delivery of an equitable service, commitment to the concepts of the community as a client and partnership working which have been identified in public health nurses in other countries (e.g., Mc Donald et al., 2013; Mc Donald and Chavasse 1997). This knowledge, these skills and attributes lie at the centre of health visiting activity and are the vehicle through which health visitors deliver topics specific to each of the four service levels set out in the HVIP (Figure 1) and described further below (DH, 2011a). 
Table 2 indicates the learning expressed as the range of knowledge, skills and abilities the review identified as necessary for working at each service level with specific examples provided below.

\section{THEME 2: EXAMPLES FROM EACH LEVEL OF SERVICE PROVISION}

\section{Building Community Capacity}

Several papers indicated that health visitors knew about public health theory but lacked skills in managing work relationships, particularly with managers who did not always understand population based working and feared that targets for individual health may not be met through a population based approach (Forester, 2004; Goodman-Brown and Appleton, 2004; Drennan et al., 2007). Health visitors in Hogg and Hanley's (2008) study also identified a potential ethical conflict between meeting public health targets (e.g for smoking cessation or breastfeeding rates), supporting communities' assessment of their own health needs and supporting community action to address these. Hogg and Hanley (2008) identified that health visitors need skills to negotiate a place of integrity between the two potentially conflicting forces and indicated that these were best obtained as part of postqualification education within the practice setting.

\section{$\underline{\text { Universal Service }}$}

The universal service is provided to all families and at its core is delivery of the Healthy Child Programme (HCP) (DH, 2009), including the mandated five key family contacts, and health promotion for the six 'high impact areas' (DH, 2014) (Figure 1). For this paper we have chosen to focus on support for breast feeding as this is central to the HCP and linked two other 'high impact areas' namely the transition to parenthood and children's achieving and maintaining a healthy weight (DH, 2014). Other examples are summarized in Table 3, with further details in the full review report (Cowley et al., 2013) and in Cowley et al. (2014), which explain how health visitors enable parents to access and use available provision (called the 'service journey') to improve and promote child and family health.

\section{Support for breastfeeding}

Although there is currently little evaluation of health visitors' impact on breastfeeding (Renfrew et al 2005) numerous studies identify what works in breastfeeding support and describe health visitors' potential to deliver this. Marshall et al (2007), for example, found mothers were best supported through a sound knowledge of breastfeeding physiology within the context of a supportive relationship. So health visitors need both the specific knowledge of breastfeeding physiology and interpersonal skills. Professionals' attitudes and the breastfeeding mother's perception of this, are also important determinants of successful breastfeeding support (Simmons, 2002 a) but Shakespeare et al (2004) described how health visitors seemed bossy and judgmental to mothers and compared 
unfavourably with midwives who were described as 'supportive'. Education, therefore, needs to include both more and better clinical information and the skills to convey this in a positive and nonjudgmental manner. Tappin et al (2006) found that post qualification education and training offered these to health visitors in a way which pre-qualification preparation alone did not, a point developed later in the paper.

\section{$\underline{\text { Universal Plus }}$}

Families use 'Universal Plus' level services when they have a specific need requiring expert intervention such as, for example, when the mother experiences low mood or post-natal depression. The prevalence of post-natal depression (10-15\% of women post delivery) means that identifying women who are suffering from this and helping to limit the impact on family life is an important part of the health visitor's work.

\section{Identifying women affected by post natal depression}

In their trial of interventions to identify and treat post-natal depression (PND), Morrell et al. (2009, 2011) provided health visitors with specialist knowledge on PND symptom identification and trained them to deliver cognitive behavioural (CBA) and person-centred interventions (PCA) to eligible women. There were improved outcomes for depressed women in the study areas, where health visitors received this additional training, over those in the control areas (Morrell et al., 2011). Further, women viewed as 'low risk' were significantly less likely to develop PND in the study areas than in the control areas, where health visitors had received no extra training (Brugha et al., 2011). Training in addition to that provided as part of the pre-qualification programme was central to the success of health these visitor interventions. Table 2 identifies the knowledge, skills and abilities involved.

\section{$\underline{\text { Universal Partnership Plus }}$}

At the universal partnership plus level the review identified randomized controlled trials of three programmes in which health visitors, used a model of communication supported by intensive training, the Family Partnership Model (FPM) (Davis and Day, 2010). FPM supports the three core health visitor practices of home visiting, relationship formation and complex needs assessment in work with families who have complex and enduring health needs.

\section{$\underline{\text { Family Partnership Model (FPM) }}$}

FPM (Davis and Day 2010) is a model for therapeutic communication wherein the helper uses skills of active listening to help the parent or family identify how best to address their own health needs and to take the steps necessary to do this. In each of the trials health visitors used different forms of knowledge plus skills and abilities to judge individual situations, inform complex health needs assessments which they acted upon using with finely honed FPM skills and abilities such as engagement, displaying genuine respect and empathy, problem exploration, challenging and goal 
setting to achieve health gain. Details of the three trials illustrating the particular health visitor skills required for this way of working are identified in Box 1. In each case the service delivery context was important as, in addition to extra post qualification training and education in the FPM, health visitors also had reduced caseloads and so the opportunity to visit families intensively; giving time in the way that adhering to the FPM requires.

In summary, the orientation to practice and the three core practices identified the generic knowledge, skills and abilities needed for health visitors. Research reviewed for the levels of practice affirmed these and contributed to our understanding of how health visitors need to function in order to deliver the service. Together they illustrate the complexity of what students need to learn in order to work salutogenically within the current system.

Several studies also described what happens when health visitors do not demonstrate these abilities in practice. Bacchus et al. (2003), for example, found that health visitors lacked the requisite knowledge of indicators for domestic violence, knowledge of appropriate services, or communication skills to intervene effectively. Robinson and Spilsbury (2008), Peckover (2003a,b) and Frost (1999) had similar findings. Merely being within the home is not enough to bring about change. Several studies (Almond and Lathlean, 2011; Tranter et al. 2010) also identified the particular, and often unmet challenges, for health visitors in effecting cross-cultural communication in order to bring the HCP to families of different ethnic origin and sometimes in extreme need through asylum seeking and possible also lack of access to public funds. In these studies health visitors were identified as having the commitment to make health creating change but possessed neither the knowledge of what was best to do nor the skills or time for relationship formation or thorough and on-going needs assessment.

\section{EDUCATIONAL MESSAGES FROM THE REVIEW}

In this section we draw on international literature and on our experience of educating health visitors to interpret the messages from the review and explain the particular learning that health visitor students need. We begin by identifying the challenges for education and conclude by considering three possible educational responses.

\section{The International Perspective}

According to The World Health Organization (WHO) estimations, there are probably around 400 schools of public health around the world (excluding medical schools). Retrieval of international literature indicated an unequal distribution of accredited schools with a predominance in the United States of America (40 accredited schools) and fewer in Africa (12 schools) and South Asia (50 schools), where the population is larger than the USA's population (Petrakova and Sadana, 2007). Regarding the training, faculty and curriculum, Petrakova and Sadana, 2007 highlight the challenge of providing health professionals with appropriate skills and competences. While some schools focus on getting the appropriate balance between teaching and research; others, particularly in low-and middle- 
income countries, focus on training to develop specific competence related to a country's health system. Public health schools in low-income countries suffer a continued lack of adequately prepared academic staff. In many countries, graduates' competencies are not well matched to the populations' needs, specifically in the field of health policy, leadership and management.

The international search also showed that literature mainly focuses on developed countries, such as the United States, Canada, and the European Union countries that joined the Union before 2004. There is a lack of evidence regarding public health nursing education in low-income countries worldwide, and those Eastern European countries which formed part of the Eastern Enlargement of the European Union between 2004 and 2007.The international literature reported a lack of uniformity in the preparation and/or role of public health nurses from one country to another, which creates the potential for cultural, ethical, and competence challenges (European Commission, 2000; Hemingway, et al., 2012). For example, policy initiatives have supported an examination of the deployment and mobility of the nursing workforce with the European Union (EU), aiming at standardizing variations in skills, qualifications, working practices and methods, culture and attitudes of public health nurses throughout the European Union (Bologna, 1999; Lisbon European Council, 2000). The Bologna Declaration, 2010, aimed to design a competitive and compatible European Higher Education Area (EHEA) with the creation of the European Credit Transfer System (ECTS). A similar project is The European Health Care Training and Accreditation Network (ETHAN), created to ameliorate the transparency of nursing work practices and education and facilitate nurse workforce mobility through a skills competency matrix (Cowan, Wilson-Barnett and Norman, 2006; Cowan, Norman and Coopamah, 2005a; EHTAN, 2005). The International Council of Nurses (ICN) initiated development of a global competencies framework (ICN, 2003) and the Standing Committee of Nurses of the European Union $(\mathrm{PCN})$ advocates for a transparent and faster recognition of European nurse qualifications (PCN, 2005). Despite these initiatives, it has been reported that the European Commission, (EC 2005) experiences difficulties in assimilating different levels of education programmes and qualifications with different outcomes (De Raeve, 2004).

\section{Challenges for education}

Research showed that, to deliver the four levels of service provision, provide health promotion at the key contact times and to address the six high impact areas health (see Figure 1) visitors require skills and particular types and of knowledge of a number of different topics. Within the European Union (EU), the United Kingdom pre-registration education provides some of this but the preparedness of each student group is extremely varied given that entrants are from different nursing branches and midwifery. In the European Union public health nurses also work in various settings and age groups: patients' homes, pediatric wards, hospitals, crèches; infants and mothers to elderly people (European Commission, 2000). The workplace and skills depend upon patients' needs and the health system of the country they qualified. In the United Kingdom, midwives, for example, may have a good knowledge of breast feeding but not child development, child branch nurses may know about child development but not about labour and delivery and mental health nurses may have highly developed communication skills but know little about adult physical health. Adult branch nurses may have no knowledge of child development or family functioning. Health visitor educators, therefore, must devise programmes that can both respond to very varied individual needs and impart a large amount of knowledge in a limited period of time. Health visitor students also need to learn how to assess family risk and resilience using theoretical knowledge of, for example child development, with real children in family environments. Experience in the clinical setting is central to this type of learning, thus health visitor educators must work closely with Practice Teachers to facilitate learning 
environments in which this level of practice can be attained within the 45 week programme (Lindley, Sayer and Thurtle, 2011).

As well as new knowledge health visitor students also need to acquire new skills. The communication and assessment skills developed as nurses and midwives need to be translated and applied to the 'well' population. Health visitor students need to learn how to engage with families, which the review indicates is achieved by skillfully communicating empathy and respect for each family's unique situation and by showing respect for family views, even if these differ from policy and evidence (McMurray et al., 2004, Redsell et al., 2010). This can challenge students, especially if they disagree with the family viewpoint or deem it harmful. Working with an undifferentiated population means that health visitors need to complement skills of engagement with sophisticated skills of assessment.

To support engagement and assessment skills educators have three tasks 1) to help students see that they need to use their commitment and skill to earn entry into family life. 2) To guide students in understanding that the best opportunities for challenging existing practices, and for supporting health promoting change, occur when families feel respected, understood and valued. 3) To assist students to acquire the skills to work in this way, which takes time.

In addition to new knowledge and skills, the review identified that health visitors must expand their abilities and change their attitudes and values in order to deliver health enhancing (salutogenic) practice. The health visiting orientation and the three associated core practices require a profound appreciation of the environment or the ecology of family life and the different systems and dynamics that influence this. For this, students need a deeper understanding of disciplines such as social science, social policy and psychology than is usually possible to incorporate within first-level nurse registration. Public health nurses in other countries have faced difficulties in imparting this scope of knowledge (e.g., Mc Donald et al., 2013, Kemp et al 2005) and British educators are challenged to achieve this within a time-limited 45 week programme.

The review upon which this paper is based (Cowley et al 2013) highlighted good evidence that when health visitors have sufficient expertise in the knowledge, skills and abilities identified above they can contribute to significant health gain for children and families (e.g., Barlow et al., 2010, Davis and Tsianis., 2005; Puura et al., 2005a,b, Kemp et al., 2011). This paper suggests that the knowledge, skills and abilities needed are demonstrably more complex than those required for first-level registration and inevitably students need time to learn, develop and practice these. It may be that a higher academic level is needed and that health visitor programmes of preparation should be at Master's level and, if so, then, once again, more time will be needed.

\section{RECOMMENDATIONS FOR EDUCATION: A RADICAL RE-THINK: IMPARTING THE KNOWLEDGE, SKILLS AND ABILITIES FOR HEALTH VISITOR PRACTICE IN BRITAIN}

Health visitor preparation is a large educational agenda complicated by the fact that students commence from very different starting points (Beck and Boulton, 2016). In the United Kingdom, imparting the knowledge skills and abilities needed for the orientation to practice, the three core health visitor practices and topic based knowledge to support the key contacts with families and high 
impact areas is a challenge for programmes of 45 weeks duration. One educational response to this would be to extend the current time for education with students either taking optional modules at the beginning of the programme or an extended period of consolidation at the end, or both. Optional modules at the beginning of the programme would allow students to compensate for the variations in their nurse or midwifery education, bringing all students up to the same point at the start of their health visitor preparation. Extending the period of consolidation would allow more time to incorporate theory and practice and for developing those sophisticated engagement and communication skills critical to achieving health gains. We suggest that re-configured programmes such as this should be up to two years duration.

A second educational response could be to develop a different form of programme for direct entry with the equivalent of one year of nursing preparation and three years of health visiting instead of the current three years of nursing and one year of health visiting. The 'Shape of Caring, Raising the Bar review of nurse education (Willis, 2015) points to the possibility of this approach. It would address many of the difficulties we identified with the current provision but would need legislative change.

Finally a third educational response could be to formalize post-qualification education so that neophyte health visitors are required to work in 'training posts', along the lines of those in medical careers, to ensure they develop sufficient skills and knowledge after their initial qualification. Once again, recent directive guidance on nurse education (Willis, 2015) suggest this as a possibility and several authors whose work we reviewed also highlighted the potential for this option (Hogg and Hanley, 2008; Simmons, 2002a,b). Professional organizations such as the Institute of Health Visiting have begun to develop post qualification Continuous Professional Development (CPD) curriculae with this in mind (Bishop et al., 2015). Although worthy of consideration, as long as CPD remains optional, practice will remain variable.

\section{CONCLUSION}

In conclusion the research we reviewed identified the potential for health visitors to bring health gain to children and families but in order to achieve this they need expert knowledge, skills and abilities. It is currently difficult to impart these within the limited time frame of the health visitor programme. This presents a challenge for health visitor educators and we have presented three main ways to achieve change; each of which involves extending or re-configuring the programme of health visitor preparation. We suggest that maintaining the current status quo, of a 45 week post-initial preparation, is not an option.

\section{Acknowledgment}


This Paper was drawn from a study that was commissioned and supported a study that was commissioned and supported by the Department of Health in England as part of the work of the Policy Research Programme(Health Visitor programme of research ref: 0160058).The views expressed are those of the authors and not necessarily those of the Department Of Health. 
Box 1: Home visiting programmes: Interventions, outcomes and skills 
1. Oxford Intensive Home Visiting study (Barlow et al 2003,, 2005; Barlow, Davis et al., 2007a,b)

Intervention: weekly visits starting early in pregnancy from a health visitor trained in the Family Partnership Model (FPM).

Outcomes: Mothers who received a visit from the FPM trained health visitor (intervention group) showed better maternal sensitivity and infant cooperativeness compared to those in the control group

Skills: In advanced assessment and especially in identifying and promoting indicators of parental bonding and parental sensitivity during pregnancy,

- Skills in helping parents change

- Skills in focusing on the needs of both mother and baby including the maternal infant relationship

- Helping without being directive

- Developing trusting relationships

- Assessing individual risk and resilience factors in families prenatally and using these to determine the level of future health visiting support

- Drawing evidence based theories to help parents and carers manage difficult and challenging issues which may affect their transition to parenthood e.g. parental and infant disability, chronic illness, perinatal depression, toxic stress, family conflict and social isolation

- Recognise signs of relationship distress and refer to specialist services where necessary

- Observe parent-infant interaction and use strengths based interventions to support sensitive parent-infant interaction

- Facilitate one-to-one interventions at home visits with the family using strengths based parenting approaches

2. European Early Prevention Project (Davis and Tsianis, 2005; Puura et al,,2005a,b)

Intervention: ante-natal and post-natal (promotional) interview and follow-up from health visitors (or the equivalent elsewhere in Europe) trained in the FPM

Outcomes: improved infant/mother interaction, in the form of mothers giving more and better positive signals to their infant and in infant responsiveness to those signals.

- Skills: assessment of maternal infant relationship and home environment

- Using the assessment to identify the required future level of health visiting support

- Challenging parental behaviours which may be harmful or increase infant risk and vulnerability

- Recognise signs of relationship distress and refer to specialist services where necessary

- Observe parent-infant interaction and use strengths based interventions to support sensitive parent-infant interaction

3. Maternal and Early Childhood Sustained Home Visiting Programme (MECSH) (Kemp et al 2011), Australian programme being implemented in some English sites (Plastow, 2013)

Intervention: mothers receive the 25 home visits from the equivalent of a British 


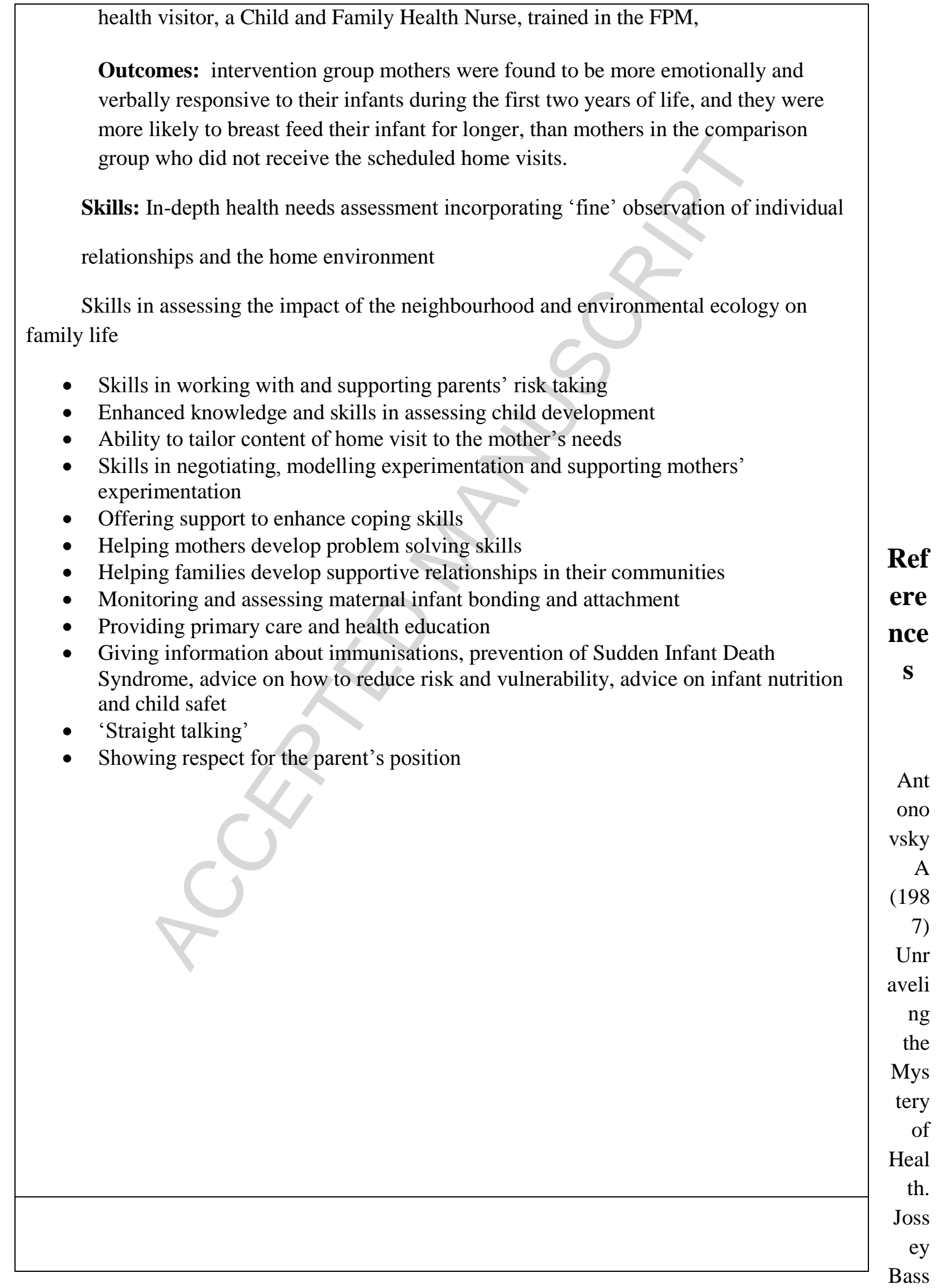

: San Francisco.

Almond, P., Lathlean, J. (2011). Inequity in provision of and access to health visiting postnatal depression services. Journal of Advanced Nursing, 67(11), 2350-2362. 
Appleton, J. V., Cowley, S. (2008a). Health visiting assessment - unpacking critical attributes in health visitor needs assessment practice: A case study. International Journal of Nursing Studies, 45(2), 232-245.

Appleton, J. V., Cowley, S. (2008b). Health visiting assessment processes under scrutiny: A case study of knowledge use during family health needs assessments. International Journal of Nursing Studies, 45(5), 682-696.

Arksey, H., O'Malley, L. (2005). Scoping studies: towards a methodological framework. International journal of social research methodology, 8(1), 19-32.

Asahara, K., Kobayashi, M., Ono, W. (2015). Moral competence questionnaire for public health nurses in Japan: Scale development and psychometric validation. Japan Journal of Nursing Science, 12, 18-26.

Austerberry, H., Wiggins, M., Turner, H., \& Oakley, A. (2004). RCT Part One: Evaluating social support and health visiting. Community Practitioner, 77(12), 460-464.

Bacchus, L., Bewley, S., and Mezey, G. (2003). Experiences of seeking help from health professionals in a sample of women who experienced domestic violence. Health and Social Care in the Community, 11(1), 10-18.

Bandura, A. (1982). Self-efficacy mechanism in human agency. American Psychologist, 37, 122-147.

Barlow, J., Stewart-Brown, S., and Callaghan, H. (2003). Working in partnership: the development of a home visiting service for vulnerable families. Child Abuse Review. (3):89

Barlow, J., Davies, H., McIntosh, E., Jarrett, P., Mockford, C., and Stewart-Brown, S. (2007a). Role of home visiting in improving parenting and health in families at risk of abuse and neglect: results of a multicentre randomised controlled trial and economic evaluation. Child: Care Health \& Development, 33(4), 505-505.

Barlow, J., Davis, H., McIntosh, E., Jarrett, P., Mockford, C., and Stewart-Brown, S. (2007b). Role of home visiting in improving parenting and health in families at risk of abuse and neglect: results of a multicentre randomised controlled trial and economic evaluation. Archives of Disease in Childhood, 92(3), 229-233.

Barlow, J., Kirkpatrick, S., Stewart-Brown, S., and Davis, H. (2005). Hard-to-reach or out-of-reach? Reasons why women refuse to take part in early interventions. Children \& Society, 19(3), 199-210.

Barlow, J., Whitlock, S., Hanson, S., Davis, H., Hunt, C., Kirkpatrick, S., et al. (2010). Preventing obesity at weaning: parental views about the EMPOWER programme. Child: Care, Health \& Development, 36(6), 843-849.

Bateson, K. J., Delaney, J., and Pybus, R. (2008). Meeting expectations: the pilot evaluation of the Solihull Approach Parenting Group. Community Practitioner, 81(5), 28-31.

Bedford, H., Lansley, M. (2006). Information on childhood immunisation: parents' views. Community Practitioner, 79(8), 252-255. 
Beck, A.J., Boulton, M.L. (2016). The public health nurse workforce in U.S. state and local health departments, 2012. Public Health Reports, 131, 145-152.

Bidmead, C. (2013). Health visitor/parent relationships: a qualitative analysis. Excerpt from 'The development and validation of tools to measure the parent/health visitor relationship,' Unpublished PhD thesis, King's College London. Reproduced in Appendix 1 to this report.

Bishop P., Gilroy, V., Stirling, L. (2015) a National Framework for Continuing Professional Development for Health Visitors - Standards for the Hight Impact Areas for Early Years. Institute of Health Visiting : London.

Bologna Process. (1999). Available from: <www.bologna-berlin2003. de/pdf/Prague_communiquTheta.pdf>.

Brocklehurst, N., Barlow, J., Kirkpatrick, S., Davis, H., and Stewart-Brown, S. (2004). The contribution of health visitors to supporting vulnerable children and their families at home. Community Practitioner, 77(5), 175-179.

Bronfenbrenner, U. (1979). The Ecology of Human Development: Experiments by Nature and Design. London: Harvard University Press.

Brugha, T. S., Morrell, C., Slade, P., and Walters, S. (2011). Universal prevention of depression in women postnatally: cluster randomized trial evidence in primary care. Psychological Medicine, 41(4), 739.

Bryans, A. (2005). At home with clients: a study of health visiting expertise. Community Practitioner, 78(10), 358-362.

Bryans, A., Cornish, F., and McIntosh, J. (2009). The potential of ecological theory for building an integrated framework to develop the public health contribution of health visiting. Health \& Social Care in the Community, 17(6), 564-572.

Byrne, E., Holland, S., and Jerzembek, G. (2010). A Pilot Study on the Impact of a Home-based Parenting Intervention: Parents Plus. Child Care in Practice, 16(2), 111-127.

Cairney, P. Alder, E., Barbour, R.S. (2006). Support for infant feeding: mothers' perceptions, British Journal of Midwifery, 14(12): 694-700

Chalmers, K. (1994). Difficult work: health visitors' work with clients in the community. International Journal of Nursing Studies, 31(2), 168-182.

Chalmers, K. I. (1992). Giving and receiving: an empirically derived theory on health visiting practice 185. Journal of Advanced Nursing, 17(11), 1317-1325.

Chalmers, K. I. (1993). Searching for health needs: the work of health visiting 184. J Adv Nurs, 18(6), 900-911.

Chalmers, K. I., Luker, K. A. (1991). The development of the health visitor-client relationship. Scandinavian Journal of Caring Sciences, 5(1), 33-41. 
Christie, J., Poulton, B. C., and Bunting, B. P. (2008). An integrated mid-range theory of postpartum family development: a guide for research and practice. Journal of Advanced Nursing, 61(1), $38-50$.

Collinson, S., Cowley, S. (1998a). An exploratory study of demand for the health visiting service within a marketing framework. Journal of Advanced Nursing, January paper, 28(3), 499-507.

Collinson, S., Cowley, S. (1998b). Exploring Need: taking the marketing perspective. Community Practitioner, 71, 244-247.

Council for the Education and Training of Health Visitors (CETHV) (1977). An investigation into the Principles and Practice of health Visiting. London Council for the Education and Training of Health Visitors.

Cowan, D.T., Norman, I.J., Coopamah, V.P. (2005a). European healthcare training and accreditation network. British Journal of Nursing, 14, 613-617.

Cowan, D.T., Wilson-Barnett, J., Norman, I.J. (2007). A European survey of general nurses' self assessment of competence. Nurse Education Today, 27, 452-458.

Cowley, S. (1991). A symbolic awareness context identified through a grounded study of health visiting. Journal of Advanced Nursing, 16, 648-656.

Cowley, S. (1995a). Health-as-process: a health visiting perspective. Journal of Advanced Nursing, 22(3), 433-441.

Cowley, S. (1995b). In health visiting, a routine visit is one that has passed. Journal of Advanced Nursing, 22(2), 276-284.

Cowley, S., Billings, J. R. (1999). Resources revisited: salutogenesis from a lay perspective. Journal of Advanced Nursing, 29(4), 994-1004.

Cowley, S., Caan, W., Dowling, S., and Weir, H. (2007). What do health visitors do? A national survey of activities and service organisation. Public Health, 121(11), 869-879.

Cowley S., Whittaker K., Grigulis, A., Malone, M., Donetto, S., Wood, H., Morrow, E., Maben, J., (2013). Why health visiting? A review of the literature about key interventions, processes and outcomes for children and families. National Nursing Research Unit, King's College London.

Cowley, S., Whittaker, K., Malone, M., Donetto, S., Grigulis, A., Maben, J. (2014). Why health visiting?Examining the potential public health benefits from health visiting practice within a universal service: a narrative review of the literature. International Journal of Nursing Studies 52: 465-480.

Craig, J., Power, C. (2010). Service innovation 'on the cheap': the development of a health visitor/tier 2 CAMHS partnership. Clinical Psychology Forum, 205 (1), $42-45$.

Davis, H., Day, C. (2010). Working in Partnership: The Family Partnership Model: Pearson.

Davis, H., Dusoir, T., Papadopoulou, K., Dimitrakaki, C., Cox, A., Ispanovic-Radojkovic, V., et al. (2005). Child and Family Outcomes of the European Early Promotion Project. International Journal of Mental Health Promotion, 7, 63-81. 
Davis, H., Tsiantis, J. (2005). Promoting Children's Mental Health: The European Early Promotion Project (EEPP). International Journal of Mental Health Promotion, 7(1), 4-16.

de la Cuesta, C. (1994a). Marketing: a process in health visiting. Journal of Advanced Nursing, 19(2), 347-353.

de la Cuesta, C. (1994b). Relationships in health visiting: enabling and mediating. International Journal of Nursing Studies, 31(5), 451-459.

Deave, T. (2003). Mothers' views on the First Parent Health Visitor Scheme. Community Practitioner, 76(7), 252-256.

Deave, T., Johnson, D., and Ingram, J. (2008). Transition to parenthood: the needs of parents in pregnancy and early parenthood. 8,. http://www.biomedcentral.com/1471-2393/8/30

Department for Education and Skills. (2004). Every Child Matters: Change for Children. London: Crown Copyright.

Department of Health (2011a). Health Visitor Implementation Plan 2011-2015: A call to action London: Department of Health.

Department of Health (2011b). Educating Health Visitors for a Transformed Service available at :https://www.gov.uk/government/news/educating-health-visitors-for-a-transformed-service (accessed 08/06/2015).

Department of Health and Department for Children Schools and Families. (2009a). The Healthy Child Programme: Pregnancy and the first five years of life. London: Department of Health.

Department of Health and Department for Children Schools and Families. (2009b). Healthy Child Programme: the two year review London: Department of Health.

Department of Health (2014). Overview of the Six Early Years High Impact Areas. Available at https://www.gov.uk/government/uploads/system/uploads/attachment_data/file/413127/29031 10_Early_Years_Impact_GENERAL_V0_2W.pdf (accessed 08/06/2015).

De Raeve, P. (2004). The free movement of nurses: a win-win situation if based on ethical recruitment guidelines. Eurohealth (3), 24-26.

Drennan, V., Davis, K., Goodman, C., Humphrey, C., Locke, R., Mark, A., et al. (2007). Entrepreneurial nurses and midwives in the United Kingdom: an integrative review. Journal of Advanced Nursing, 60(5), 459-469.

Drennan, V. M., Joseph, J. (2005). Health visiting and refugee families: issues in professional practice. Journal of Advanced Nursing, 49(2), 155-163.

Edge, D. (2007). 'We don't see Black women here': an exploration of the absence of Black Caribbean women from clinical and epidemiological data on perinatal depression in the UK. Midwifery, 24, 379-389.

Edge, D. (2010). Falling through the net. Black and minority ethnic women and perinatal mental healthcare:health professionals' views. General hospital psychiatry, 32 (1), 17-25. 
Edge, D. (2011). 'Its leaflet, leaflet, leaflet then, see you later':Black Caribbean women's perceptions of perinatal mental health care. Britiah Journal of General Practice, 61(585), 256-262.

European Healthcare Training and Accreditation Network (EHTAN). (2005). Available from: <www.kcl.ac.uk/nursing/research/ehtan>.

European Commission. (2000). MARKT/D/8031/2000. Reference XV/98/09/E. European Commission, Brussels.

European Commission. (2005). Directive 2005/36/EC on the recognition of professional qualifications. European Commission, Brussels.

Fatherhood Institute. (2008). The Dad Deficit: The Missing Piece in the Maternity Jigsaw. Abergavenny: Fatherhood Institute.

Fatherhood Institute (2011) Fathers, Mothers, Work and Family. Abergavenny: Fatherhood Institute.

Forester, S. (2004). Adopting community development approaches. Community Practitioner, 77(4), $140-145$.

Feldman, R. (2006). Primary health care for refugees and asylum seekers : a review of the literature and a framework for services. Public Health, 120 (9), 809-816.

Frost, M. (1999). Health visitors' perceptions of domestic violence: the private nature of the problem. Journal of Advanced Nursing, 30(3), 589-596.

Goodman-Brown, J., and Appleton, J. V. (2004). How do health visitors perceive their public health role? 1068. Community Practitioner, 77 (9), 333-337.

Halpin, J., Nugent, B. (2006). Health visitors' perceptions of their role in autism spectrum disorder Community Practitioner, 80 (1), 18-22.

Hanafin, S., Cowley, S. (2006). Quality in preventive and health-promoting services: constructing an understanding through process. Journal of Nursing Management, 14(6), 472-482.

Harrison, S. Berry, L. (2006). Valuing people: health visiting and people with learning disabilities. Community Practitioner, 79 (2) 56-59.

Hemingway, A., Aarts, C., Koskinen, L., Campbell, B., Chassé, F. (2012). A European Union and Canadian Review of Public Health Nursing Preparation and Practice. Public Health Nursing, 30(1), 58-69.

Hoddinott, P., Britten, J., et al. (2009). "Effectiveness of policy to provide breastfeeding groups (BIG) for pregnant and breastfeeding mothers in primary care: cluster randomised controlled trial." BMJ British Medical Journal 338, (7691) doi:10.1136/bmj.a3026.

Hoddinott, P., Lee, A. and Pill, R. (2006). Effectiveness of a breastfeeding peer coaching intervention in rural Scotland. Birth, 33 (1) 27-36.

Hogg, R., Hanley, J. (2008). Community development in primary care: opportunities and challenges. Community Practitioner, 81(1), 22-25. Discussion tool. Journal of Reproductive and Infant Psychology, 25(3), 210-222. 
International Council of Nurses (ICN), (2003). Framework of competencies for the generalist nurse. International Council of Nurses, Geneva, Switzerland.

Jenkins, M., Parylo, C. (2011). Evaluation of health services received by homeless families in Leicester. Community Practitioner, 84 (1), 21-4.

Kemp L, Anderson T, Travaglia J, Harris E. (2005). Sustained nurse home visiting in early childhood: exploring Australian nursing competencies. Public Health Nursing 2005; 22(3), 254-9.

Kemp, L., Harris, E., McMahon, C., Matthey, S., Vimpani, G., Anderson, T., et al. (2011). Child and family outcomes of a long-term nurse home visitation program: a randomised controlled trial. Archives of Disease in Childhood, 96, 533-540.

Kendall, S. (1993). Do health visitors promote client participation? An analysis of the health visitor client interaction 316. Journal of Clinical Nursing, 2(2), 103-109.

Lindley, P.J., Sayer, L., Thurtle, V.J. (2011). Current educational challenges for specialist community public health nurses following a health-visiting pathway and the consequences of these challenges for public health. Perspectives in Public Health, 131(1), 32-7.

Ling, M., Luker, K. (2000). Protecting children: intuition and awareness in the work of health visitors Journal of Advanced Nursing, 32 (3), 572-579.

Lisbon European Council, 2000. Lisbon strategy. Available from : <www.europa.eu.int/comm/lisbon_strategy/index_en.html>.

Luker, K. A., Chalmers, K. I. (1989). The referral process in health visiting International Journal of Nursing Studies, 26(2), 173-185.

Luker, K. A., Chalmers, K. I. (1990). Gaining access to clients: the case of health visiting 188. Journal of Advanced Nursing, 15(1), 74-82.

Marks, L., Mcconnell, J., and Baker, M. (2005). Broader skills for working with perinatal depression. Community Practitioner, 78(8), 280-282.

Marshall, J. L., Renfrew, M. J., and Godfrey, M. (2006). Using evidence in practice: What do health professionals really do?: A study of care and support for breastfeeding women in primary care. Clinical Effectiveness in Nursing, 9, Suppl 2, e181-e190.

Marshall, J. L., Godfrey, M., et al. (2007). "Being a 'good mother': Managing breastfeeding and merging identities." Social Science \& Medicine 65(10): 2147-2159.

McDonald, A., Chavasse, J.(1997) Community participation within an Irish Health Board area. British Journal of Nursing 6 (6) 341-5

McDonald, A., Frazer, K., Cowley, S. (2013) Caseload Management : an approach o making community needs visible. British Journal of Community Nursing 3 (183) 140-147

McIntosh, J., Shute, J. (2007). The process of health visiting and its contribution to parental support in the Starting Well demonstration project. Health \& Social Care in the Community, 15(1), 7785. 
McMurray, R., Cheater, F. M., Weighall, A., Nelson, C., Schweiger, M., and Mukherjee, S. (2004). Managing controversy through consultation: A qualitative study of communication and trust around MMR vaccination decisions. British Journal of General Practice, 54(504), 520-525.

Merrifield, R. (2005). Evaluation of a health visitor-led sleep and behaviour clinic. Community Practitioner, 78(8), 283-288.

Morgan A and Ziglio E. Revitalising the evidence base for Public Health : an assetts model. Promotion and Education 2007; Suppl 2:17-22.

Morrell, C. J., Ricketts, T., Tudor, K., Williams, C., Curran, J., and Barkham, M. (2011). Training health visitors in cognitive behavioural and person-centred approaches for depression in postnatal women as part of a cluster randomised trial and economic evaluation in primary care: the PoNDER trial. Primary Health Care Research \& Development, 12, 11-20.

Morrell, C. J., Slade, P., Warner, R., Paley, G., Dixon, S., Walters, S. J., et al. (2009). Clinical effectiveness of health visitor training in psychologically informed approaches for depression in postnatal women: pragmatic cluster randomised trial in primary care. BMJ: British Medical Journal, 338, (7689) 1-14. doi: 10.1136/bmj.a3045.

Nursing \& Midwifery Council (2004). Standards of Proficiency for Specialist Community Public Health Nurses. London, Nursing and Midwifery Council

NHSE (NHS England) (2014). Five Year Forward View. NHS England: London Available at: http: //www.england.nhs.uk/wp-content/uploads/2014/10/5yfvweb. (Accessed 08/06/2015).

Orford, J., Templeton, L., Patel, A., Copello, A., and Velleman, R. (2007a). The 5-Step family intervention in primary care: I. Strengths and limitations according to family members. Drugs: Education, Prevention, and Policy, 14(1), 29-47.

Orford, J., Templeton, L., Patel, A., Velleman, R., \& Copello, A. (2007b). The 5-Step family intervention in primary care: II. The views of primary healthcare professionals. Drugs: Education, Prevention, and Policy, 14(2), 117-135.

Papadopoulou, K., Dimitrakaki, C., Davis, H., Tsiantis, J., Dusoir, A., Paradisiotou, A., et al. (2005). The effects of the European Early Promotion Project training on primary health care professionals. International Journal of Mental Health Promotion, 7, 54-62.

PCN Standing Committee of Nurses of the European Union, 2005. Available from: <www.pcnweb.org/EN/positions_statements>.

Pearson, P. (1991). Clients' perceptions: the use of case studies in developing theory 4. Journal of Advanced Nursing, 16(5), 521-528.

Peckover, S. (2003a). Health visitors' understandings of domestic violence. Journal of Advanced Nursing, 44(2), 200-208.

Peckover, S. (2003b). 'I could have just done with a little more help': an analysis of women's helpseeking from health visitors in the context of domestic violence. Health \& Social Care in the Community, 11(3), 275-282. 
Petrakova, A., Sadana, R. (2007) Bull World Health Organ. 85 (12) 963-5

Plastow , L. (2013). Implementing maternal early childhood sustained home visiting. Essex Journal of Health Visiting, 1(2), 96-103.

Plews, C., Bryar, R., and Closs, J. (2005). Clients' perceptions of support received from health visitors during home visits. Journal of Clinical Nursing, 14(7), 789-797.

Pugh, G., Duffy, B. (2010). Contemporary Issues in The Early Years (Vol. 5th). London: Sage.

Puura, K., Davis H., Mäntymaa M., et al. (2005b). The Outcome of the European Early Promotion Project: Mother-Child Interaction. International Journal of Mental Health Promotion, 7(1), 82-94.

Puura, K., Davis, H., Cox, A., Tsiantis, J., Tamminen, T., Ispanovic-Radojkovic, V., et al. (2005a). The European Early Promotion Project: Description of the Service and Evaluation Study. International Journal of Mental Health Promotion, 7, 17-31.

Redsell, S. A., Bedford, H., Siriwardena, A. N., Collier, J., and Atkinson, P. (2010). Health visitors' perception of their role in the universal childhood immunisation programme and their communication strategies with parents. Primary Health Care Research and Development, $11(1), 51-60$.

Renfrew, M., Dyson, L., Wallace, L., D'Souza, L., Mc Cormick, F., Spilby, H. (2005). The Effectiveness of Public Health Interventions to Promote the Duration of Breastfeeding. Systematic Review ( $1^{\text {st }}$ ed.) London: NICE.

Robinson, L., Spilsbury, K. (2008). Systematic review of the perceptions and experiences of accessing health services by adult victims of domestic violence. Health \& Social Care in the Community, 16(1), 16-30.

Salway, S., Chowbey, P., and Clarke, L. (2009). Parenting in modern Britain: understanding the experiences of Asians fathers. Joseph Rowntree Foundation \& York Publishing: York.

Shakespeare, J., Blake, F., and Garcia, J. (2004). Breast-feeding difficulties experienced by women taking part in a qualitative interview study of postnatal depression. Midwifery, 20(3), 251260 .

Sikorski, J., Renfrew, M.J., Pindoria, S., and Wade, A. (2002) Support for breastfeeding mothers. Cochrane Database Systematic Reviews. (1) CD001141.

Simmons, V. (2002a). "Exploring inconsistent breastfeeding advice: 1." British Journal of Midwifery, 10(5), 297-301.

Simmons, V. (2002a). "Exploring inconsistent breastfeeding advice: 1." British Journal of Midwifery 10(5), 297-301.

Simmons, V. (2002b). "Exploring inconsistent breastfeeding advice: 2." British Journal of Midwifery 10(10), 616-619.

Sonuga-Barke, E. J., Daley, D., Thompson, M., Laver-Bradbury, C., and Weeks, A. (2001). Parentbased therapies for preschool attention-deficit/hyperactivity disorder: A randomized 
controlled trial with a community sample. Journal of the American Academy of Child \& Adolescent Psychiatry, 40(4), 402-408.

Spencer, R. L., Greatrex-White, S., et al. (2010). Practice improvement, breastfeeding duration and health visitors. Community Practitioner 83(9), 19-22.

Stewart-Brown, S., Patterson, J., Mockford, C., Barlow, J., Klimes, I., and Pyper, C. (2004). Impact of a general practice based group parenting programme: quantitative and qualitative results from a controlled trial at 12 months. Archives of Disease in Childhood, 89 (6), 519-525.

Tappin, D., Britten, J., Broadfoot, M., and McInnes, R. (2006). The effect of health visitors on breastfeeding in Glasgow. International Breastfeeding Journal, 5 (1) 11, doi:10.1186/17464358-1181-1111.

Tranter, S., Irvine, F., Roberts, G., Spencer, L., and Jones, P. (2010). The role of midwives and health visitors in promoting intergenerational language maintenance in the bilingual setting: perceptions of parents and health professionals. Journal of Clinical Nursing, 20, 204-213.

Turner, K. M., Chew-Graham, C., Folkes, L., and Sharp, D. (2010). Women's experiences of health visitor delivered listening visits as a treatment for postnatal depression: A qualitative study. Patient education and counseling, 78(2), 234-239.

Watson, M., Kendrick, D., and Coupland, C. (2005). Providing child safety equipment to prevent injuries: randomised controlled trial. BMJ, 330(7484), doi: 10.1136/bmj.38309.664444.664448F

Watson, M., Kendrick, D., Coupland, C., and Futers, D. (2007). Childhood injury prevention: the views of health visitors and nursery nurses working in deprived areas. International Journal of Health Promotion \& Education, 45(1), 4-10.

Whitehead, R. E., Douglas, H. (2005). Health visitors' experiences of using the Solihull approach. Community Practitioner, 78(1), 20-23.

Whittaker, K. A., Cornthwaite, S. (2000). Benefits for all: outcomes from a positive parenting evaluation study. Clinical Effectiveness in Nursing, 4(4), 189-197.

Whittaker, K. A., Cowley, S. (2012). A survey of parental self-efficacy experiences: maximising potential through health visiting and universal parenting support. Journal of Clinical Nursing. $26,138-149$.

Whittaker, K. A., Mace, J., Murphy, J., Carter, B., and Tudor-Edwards, R. (2011). The NHS East Lancashire Health Co-ordinator Role: A Realistic Evaluation of Practice. Preston: School of Health, University of Central Lancashire.

WHO (World Health Organisation). (2015). World Health Statistics 2015. WHO: Luxembourg.

Wiggins, M., Oakley, A., Roberts, I., Turner, H., Rajan, L., Austerberry, H., et al. (2004). The Social Support and Family Health Study: a randomised controlled trial and economic evaluation of two alternative forms of postnatal support for mothers living in disadvantaged inner-city areas. Health technology assessment (Winchester, England), 8(32), 1-133. 
Wiggins, M., Oakley, A., Roberts, I., Turner, H., Rajan, L., Austerberry, H., et al. (2005). Postnatal support for mothers living in disadvantaged inner city areas: a randomised controlled trial. Journal of Epidemiology and Community Health, 59(4), 288-295.

Willis, L. (2015). Raising the Bar. Shape of Caring : A Review of the Future Education and Training of Registered Nurses and Care Assistants. Available at hee.nhs.uk/wpcontent/blogs.dir/321/files/2015/03/2348-Shape-of-caring-review-FINAL.pdf (accessed 08/06/2015)

Wilkinson, S., Stöckl, A., et al. (2009). Surveying Hard to Reach Groups-Final Report. University of East Anglia.

Williams, R., Hewison, A. (2009). 'We're doing our best': African-Carribean fathers' views and experiences of fatherhood, health, and preventive primary care services: University of Birmingham, College of Medical and Dental Sciences, School of Health and Population Sciences.

Williams, R., Hewison, A., Stewart, M., Liles, C., and Wildman, S. (2012). 'We are doing our best': African and African-Caribbean fatherhood, health and preventive primary care services, in England. Health \& Social Care in the Community, 20(2), 216-223.

Wilson, P., Barbour, R. S., Graham, C., Currie, M., Puckering, C., and Minnis, H. (2008a). Health visitors' assessments of parent-child relationships: A focus group study. International Journal of Nursing Studies., 45(8), 1137-1147.

Wilson, P., Furnivall, J., Barbour, R. S., Connelly, G., Bryce, G., Phin, L., et al. (2008b). The work of health visitors and school nurses with children with psychological and behavioural problems. Journal of Advanced Nursing, 61(4), 445-455.

Woods, A., Collier, J., et al. (2004). Injury prevention training: a cluster randomised controlled trial assessing its effect on the knowledge, attitudes, and practices of midwives and health visitors. Injury Prevention 10(2), 83-87. 
Figure 1: Four levels of service delivery (DH 2011), five mandated contact points (DH 2014), six high impact areas (DH 2014).

Four Levels of Service Delivery (DH 2011)

BUILDING COMMUNUITY CAPACITY (E.G.WORKIN WITH PEOPLE IN THIER OWN ENVIRONMENTS TO HELP THEM IMPROVE THEIR OWN HEALTH

- UNIVERSAL SERVICE (OFFERED TO EVERY FAMILY, INCLUDES DELIVERY OF ALL THE ELEMENTS OF THE HEALTH CHILD PROGRAMME

- UNIVERSAL PLUS (PROVIDING EXPERT AND TIMELY HELP WITH DIFFICULTIES WHEN THEY ARISE E.G CHILDHOOD SLEEPING, EATING AND BEHAVIOURAL PROBLEMS, IDENTIFYTING SIGNS OF POST-NATAL DEPRESSION

- UNIVERSAL PARTNERSHIP PLUS (E.G. WORKING WITH WITH OTHER AGENCIES SUCH AS SOCIAL SERVICSE TO O PROMOTE HEALTH FOR FAMIIES LUVING COMPIEX O PROMOTE HEALTH FOR FAMILLES LIVING COM
LIVES AND IN DIFFICULT CIRCUMSTANCES E.G. TRANSIENT FAMILIES, THOSE WHO HAVE LIMITED ACCESS TO PUBLIC FUNDS.

- SAFEgUARDING OR MAXIMISING OPPORTUNITIES TO REDUCE RISK, PREVENT HARM TO CHILDREN AND MAXIMISE INDIVIDUAL AND FAMILY RESILIENCE RUNS THROUGH EACH OF THESE LEVEIS

- familes may PROGRESS THROUgh THe DIFFERENT FAMVIS SERVICE PROUSIONACCORO DIFEREN IDENTIFIED NEEDS
Five mandated health visitor contact points

$$
\text { (DH 2014) }
$$

- ante-natal health promotion Visits : HEALTH VISITORS MEET WITH EXPECTANT PARENTS AND BEGIN TO FORM A RELATIONSHIP WITH THEM. THE SERVICES, EXPLORES EXPECTATIONS OF PARENTHOOD AND HELPS PARTWTS THEMMHAVEA REALISTCVEW OF THIS, DISCUSSES INFANT FEEDING AND PROMOTES BREASTFEEDING.

NEW BABY REVIEW:

A FACE TO FACE REVIEW BY 14 DAYS WITH MOTHER AND

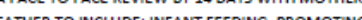
SENSITIVE PARENTING, PROMOTING DEVEOPMENT, ASSESSING MATERMA MENTAL HEATH, SUDDEN INFANT DEATH SYNDROME, KEEPING SAFE IF PARENTS WISH OR THERE ARE PROFESSONAL CONCENIS: ANT ASSESSMENT OF BABY'S GROWTH ON CONG REVIEW

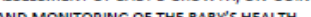
SAFGUARDING, ASSESSMENT OF ATTACHM

6- oweer assessment of mother and baer

incluDes:

ON-GOING SUPPORT WITH BREASTFEEDING INVOLVING DN-GONG SUPPORT WTH BREASTIEEDING NNOLVING

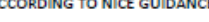

ONEYEAR ASSESSMENTT OF INFANT

INCLUDES: ASSESSMENT OF THE BABY'S PHYSICAL,

EMOTIONAL AND SOCIAL DEVELOPMENT AND

MEEDS,PROVIDE PARENTS WITH INFORMATION ABOUT

ATACHMENT AND DEVELOPMENTAL AND PARENTING

ISSUES, MONITORING GROWTH AND HEALTH

PROMOTION, E.G.RAISE AWARENESS OF DENTAL HEALTH AND HEALTHY EATING, INUURY AND ACCIDENT PREVENTION

$2-2$ AND A HALF YEAR ASSESSMENT OF THE INFANT INCLUDES: REVIEW WITH PARENTS THE CHILD'S SOCIAL, EMOTONAL, BEHAVOURAL AND LANGUAGE DEVElop PARENTAL CONCERNS ABOUT PHYSICAL HEALTH, P

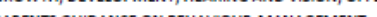
PARENT GU DANCE ON EEHAVOUR MONAGEMENT PARENT INFORMATION ON WHAT TO DO IF WORPIED

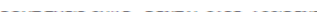
PREVENTION, SLEEP HYGIENE
Six High Impact Areas (DH 2014)

- THESE TOPICS NeED to be ADdRESSE WITHIN HEALTH VISITOR ACTIVITY AT EACH LEVEL OF SERVICE DELIVERY AND AT THE KEY CONTACT POINTS IN ORDER TO PROMOTE HEALTH AT A POPULATION
LEVEL :

- maternal mental health

- transition to parenthood

- breastfeeding

healthy Weight

- CHILD DEVELOPMENT AND SCHOOL READINESS

- PREVENTING ACCIDENTS

- managing minor IlLness 
Table 1 Examples of the learning required for health visiting core skills and orientation to practice

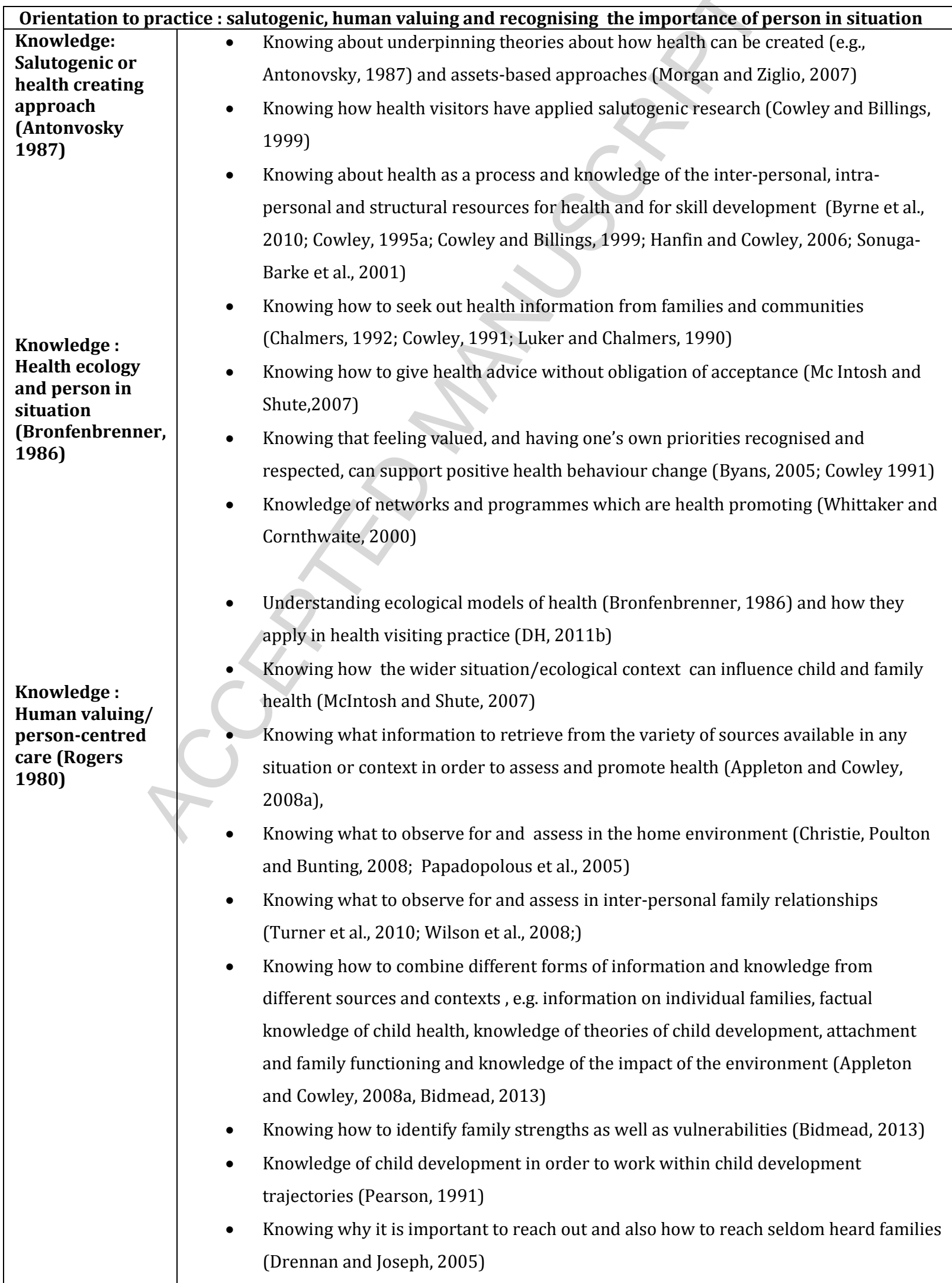




\begin{tabular}{l}
\hline Skill : Salutogenic \\
or health \\
creating \\
approach \\
(Antonvosky \\
1987) \\
\\
\\
Skill: Health \\
ecology / person \\
in situation \\
(Bronfenbrenner, \\
1986)
\end{tabular}
1986)

Skill: Human valuing/ personcentred care (Rogers 1980)
- Observational, questioning and listening skills to seek out health need (Chalmers, 1992; Cowley, 1991; Luker and Chalmers, 1990)

- Skills in health needs assessment and early identification of risk factors for children: engagement, active listening, building trust, challenging, agenda setting, planning and evaluation (Barlow et al., 2007; Davis et al., 2005)

- Health education skills : non-judgmental health information giving involving checking out existing expertise (Collinson and Cowley, 1998), checking out the family's perspective (Bryans, 2005) and providing information in a respectful manner (McIntosh and Shute, 2007)

- Skills for home visiting, including using it as a basis for knowledgeable observation (Christie, Poulton \& Bunting, 2008), for tailoring context-specific advice (Bryans 2005) and explicitly seeking the mother's perspective (Bryans, 2005)

- $\quad$ awareness of wider situation/context (McIntosh \& Shute, 2007), using interpersonal interventions and skills to help change situation/context (Cowley, 1995b; Christie et al.,2008)

- Skills in helping families to link with one another and with community resources for health gain : skills of engagement with families, skills in building families' self efficacy through active forming and strengthening inter-family connections and building families' trust in services (Cowley and Billings 1999; Davis et al., 2005; Hanafin and Cowley, 2006)

- Skills in inter-agency collaboration to support availability and delivery and additional community resources such as parenting programmes (Bateson et al., 2008; Whittaker and Cowley, 2012)

- $\quad$ Skilled tempering of instinct and gut feelings through critical reflection and consideration of information from a variety of sources (Appleton and Cowley, 2008a; Ling and Luker,2000;)

- Skills in flexible assessment and re-assessment, which is responsive to situational changes over time(Appleton and Cowley, 2008a)

- Skilled Formation of a complex professional judgement of familial risk and vulnerability vs. strength and resilience (Appleton and Cowley, 2008b)

- 'Tuning in' to family's situation (Wilson et al., 2008)

- $\quad$ Skilled interpersonal interventions involving : engagement, active listening, building trust, challenging, agenda setting, planning and evaluation to help change the situation or context (Christie et al.,2008; Cowley, 1995b; Davis et al., 2005)

- $\quad$ Skill in judging how and when to say something to optimise family's readiness to change (Appleton and Cowley, 2008b)

- $\quad$ Skill in listening to what families say they need and offering support which is specific to this ( Turner et al., 2010)

- $\quad$ Tuning in to the family (Plews et al., 2005)

- Skilled communication of respect for the family's priorities to achieve consonance (Appleton and Cowley, 2008a; Chalmers, 1992; Cowley, 1999;)

- $\quad$ Form trusting relationships as a basis for the health visiting process (Bidmead, 2013) 


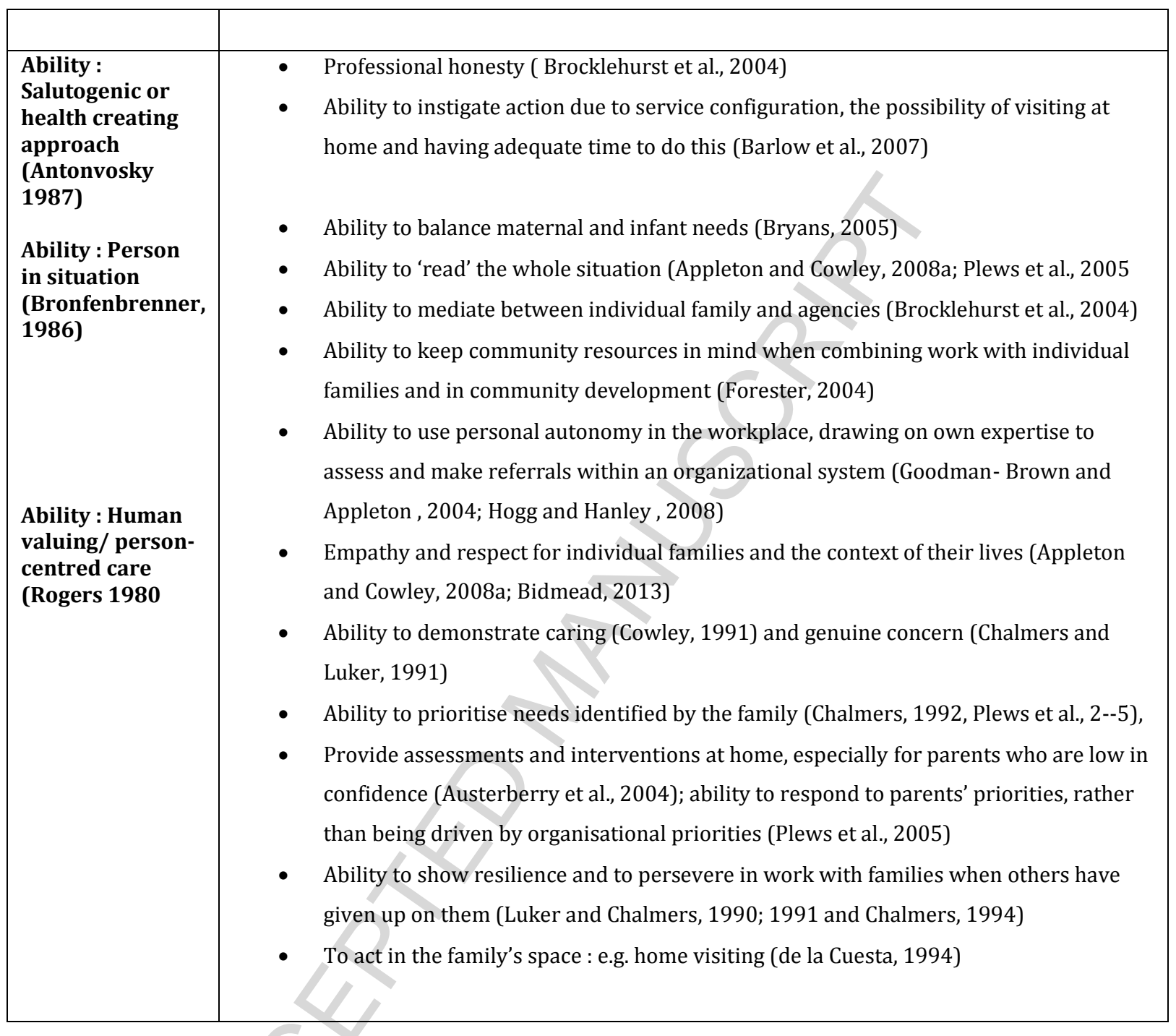




\begin{tabular}{|c|c|}
\hline $\begin{array}{l}\text { Building } \\
\text { Community } \\
\text { Capacity : } \\
\text { Knowledge }\end{array}$ & $\begin{array}{l}\text { - } \quad \text { Knowledge of public health theory (Drennan et al., 2007; Forester, 2004;) } \\
\text { Knowledge of the theory and practice of community working and of how to encourage local people in local } \\
\text { health initiatives (Goodman-Brown and Appleton, 2004); } \\
\text { - } \quad \text { Knowing how to overcome management objections to non-caseload working (Hogg and Hanley, 2008) } \\
\text { Knowing how to mediate between managerial expectations meeting targets and community aspirations for } \\
\text { - } \quad \text { Knowlth (Forester, 2004) } \\
\text { - Knowing how to create new resources for health (Cowley, 1995a) } \\
\text { - Knowing how to encourage people to develop their own resources for health (Cowley and Billings, 1999) }\end{array}$ \\
\hline $\begin{array}{l}\text { Building } \\
\text { Community } \\
\text { Capacity : Skill }\end{array}$ & $\begin{array}{l}\text { - Skills in engaging local people in health initiatives (Forester, 2004) } \\
\text { - Skills in managing relationships with both families and with managers: negotiating, mediating and } \\
\text { advocating (Hogg and Hanley, 2008) } \\
\text { Mediation skills for use between individuals and third parties (Bryans et al., 2009) } \\
\text { - } \quad \text { Prioritisation and re-prioritisation skills in order to manage workload in a way which is responsive to } \\
\text { changing professional agendas (Appleton and Cowley, 2008a, Hanafin and Cowley, 2006) } \\
\text { - Verbal persuasion skills to help local people feel more confident in own abilities to affect health change } \\
\text { (Plews et al., 2005) }\end{array}$ \\
\hline $\begin{array}{l}\text { Building } \\
\text { Community } \\
\text { Capacity : } \\
\text { Abilities }\end{array}$ & $\begin{array}{l}\text { - Ability to engage honestly with local health agenda (Brocklehurst et al 2004) } \\
\text { - Ability to accept and to work with different health agenda and different concepts of health gain ( Bryans, } \\
\text { 2005) } \\
\text { Ability to deal with ethical conflicts between accountability for meeting public health targets and supporting } \\
\text { the community's assessment of its own health needs (Forester, 2004; Hogg and Hanley, 2008) }\end{array}$ \\
\hline $\begin{array}{l}\text { Universal } \\
\text { Service: } \\
\text { Knowledge }\end{array}$ & 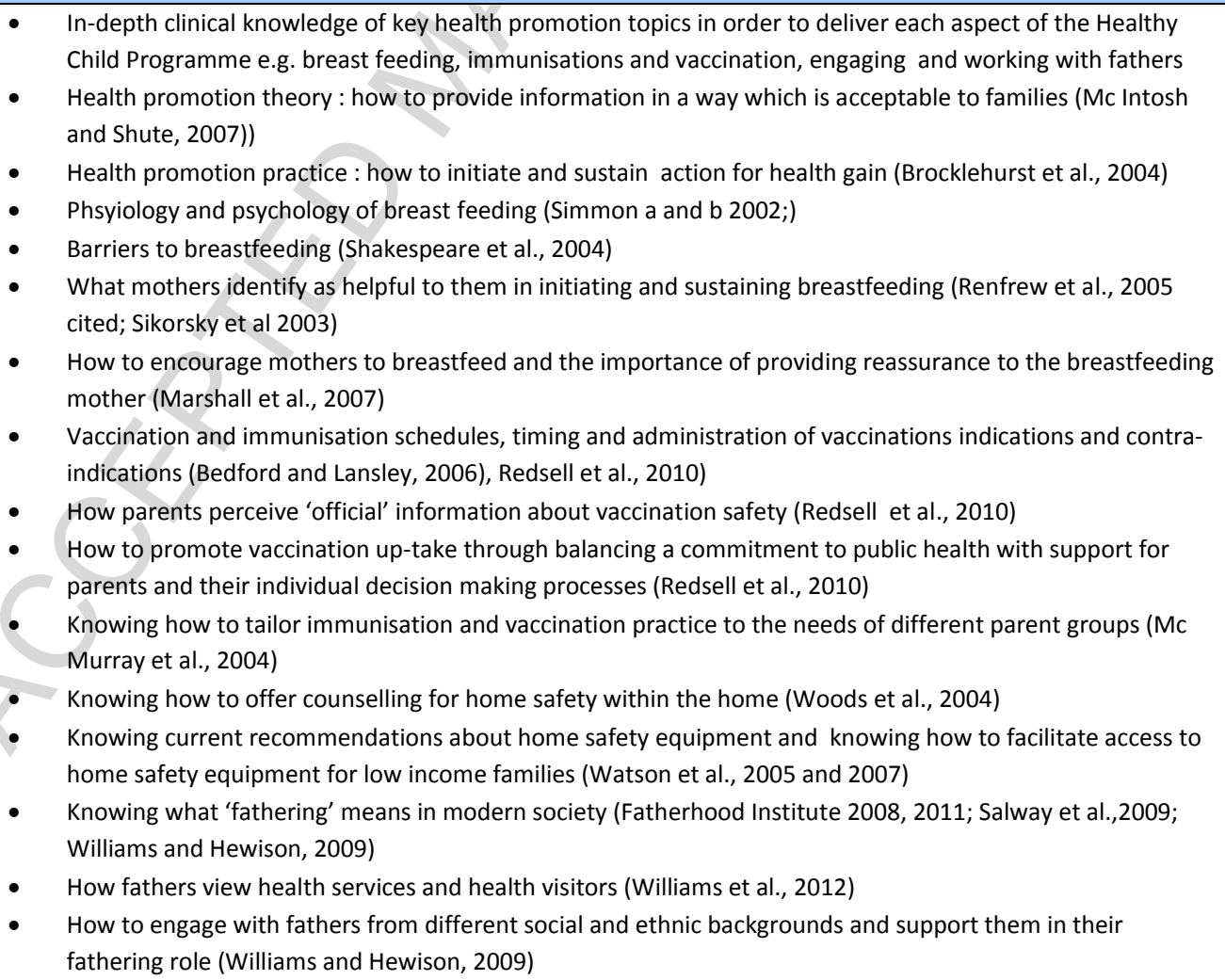 \\
\hline $\begin{array}{l}\text { Universal } \\
\text { Service: Skills }\end{array}$ & $\begin{array}{l}\text { - Seeking out health needs (Chalmers, 1992) } \\
\text { - Skills in working pro-actively especially in addressing situations of risk (Appleton and Cowley, 2008) } \\
\text { - Information giving which is effective and seen by the family as non-judgmental (Beford and Lansley, 2004; } \\
\text { - Mc Murray et al., 2004) } \\
\text { - Sommunication skills (respectful active listening) to promote engagement } \\
\text { - Skills in providing parenting information for fathers which reflects the needs of different fathering groups } \\
\text { - Skills in conveying respect for a family's viewpoint even if it is different to the 'official' view and contrary to } \\
\text { the 'evidence-base'(Redsell et al., 2010) }\end{array}$ \\
\hline Universal & Able to communicate effectively and in a non-judgemental manner (Renfrew et al., 2005 cited in Spencer et \\
\hline
\end{tabular}




\begin{tabular}{|c|c|}
\hline $\begin{array}{l}\text { Service: } \\
\text { abilities }\end{array}$ & $\begin{array}{l}\text { al, 2010; Sikorsky et al., 2003) } \\
\text { - Able to see the situation from the family's perspective especially in relation to immunisation and } \\
\text { vaccination (Redsell et al., 2010) } \\
\text { - Able to respect the family's viewpoint and their right to make decisions which may differ from the 'evidence } \\
\text { base' (Mc Murray et al 2004) } \\
\text { - } \quad \text { Able to remain hopeful for success especially in relation to breastfeeding (Simmos, } 2002 \text { a and b) } \\
\text { - Being able to take time to explain (Bedford and Lansley, 2006) }\end{array}$ \\
\hline $\begin{array}{l}\text { Universal Plus : } \\
\text { Knowledge }\end{array}$ & 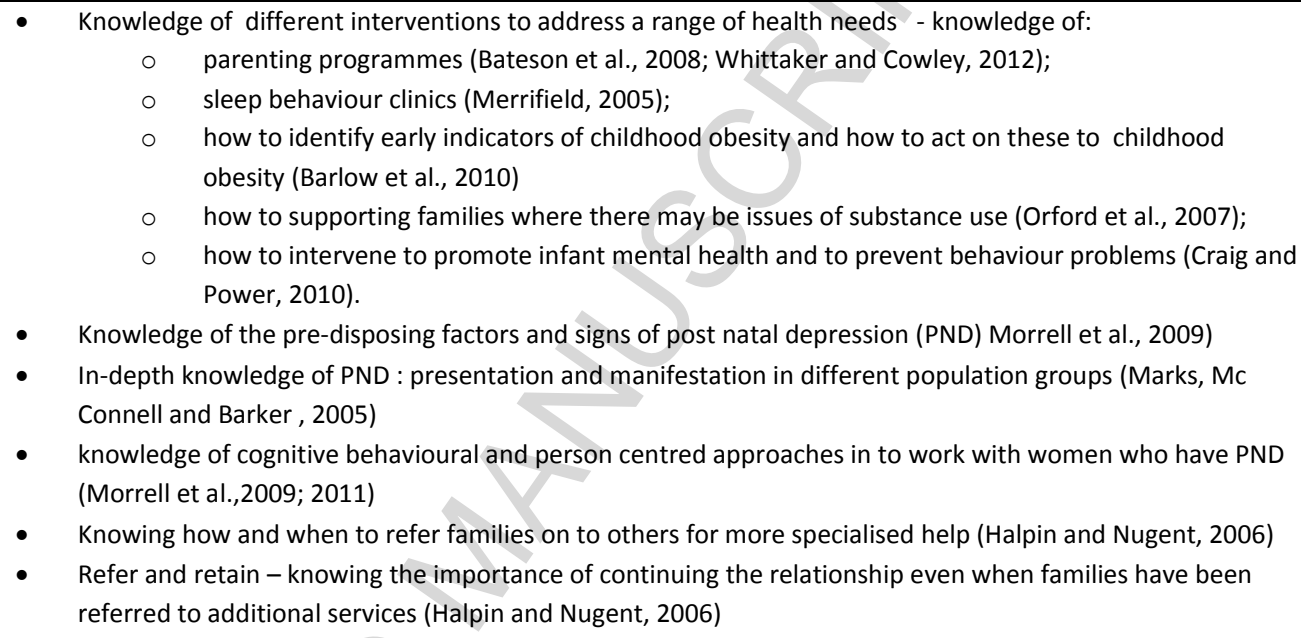 \\
\hline $\begin{array}{l}\text { Universal Plus : } \\
\text { Skills }\end{array}$ & $\begin{array}{l}\text { - } \\
\text { - } \quad \text { Skills in assessment of complex health needs (Appleton and Cowley, 2008a) } \\
\text { - } \quad \text { Finely tuned listening skills to 'unlock issues' (especially for women with PND) and assist the person's sense } \\
\text { - } \quad \text { of being able to manage their own condition (Turner et al., 2010) } \\
\text { - } \quad \text { Ability to convey respect for the individual and understanding of their unique situation (Morrell et al.,2011) } \\
\text { - } \quad \text { Active listening, conveying acceptance of the mothers' viewpoint (Morrell et al., 2011) } \\
\text { - } \quad \text { Helping the mother re-formulate her interpretation of life events and motivating healthy change (Morrell et } \\
\text { - } \quad \text { List., 2011) } \\
\text { - Skills in giving sensitive messages in a way which is meaningful and not threatening for the family and } \\
\text { which maximises their likelihood of being acted upon (Barlow et al., 2010) }\end{array}$ \\
\hline $\begin{array}{l}\text { Universal Plus: } \\
\text { Abilities }\end{array}$ & $\begin{array}{l}\text { - The ability to work with families to set small goals which reflect family relationships and family dynamics } \\
\text { (Rudolf, 2009) } \\
\text { - The ability to address relationships issues when talking with families about healthy eating and obesity } \\
\text { - } \quad \text { Helping families identify solutions to their difficulties (Barlow, 2010, Davis and Day, 2010) } \\
\text { - } \quad \text { Respect for all families Barlow, 2010, Davis and Day, 2010) } \\
\text { - The ability to experience and to demonstrate empathy with the family's e., fforts to attain health within } \\
\text { their own family environment (Barlow et al., 2010) }\end{array}$ \\
\hline $\begin{array}{l}\text { Universal } \\
\text { Partnership } \\
\text { Plus: } \\
\text { Knowledge }\end{array}$ & $\begin{array}{l}\text { - Knowledge of the factors which lead families to have complex and enduring health needs including } \\
\text { understanding sociological and psychological factors, including what makes families 'seldom heard' or } \\
\text { 'heard to reach' (Wilkinson et al., 2009) } \\
\text { - Knowing how to engage with and contribute to the experience of families where there are learning } \\
\text { difficulties or physical disabilities (Cernik et al., 2007; Harrison and Berry, 2006) } \\
\text { - Understanding impact of culture and ethnicity on family life in the UK and especially on the mental health } \\
\text { of expectant and new mothers (Edge 2007, 2010, 2011) } \\
\text { - Knowing about the impact of homelessness on family health }\end{array}$ \\
\hline
\end{tabular}




\begin{tabular}{|c|c|}
\hline & $\begin{array}{l}\text { Parylo, 2010) } \\
\text { Knowing about the prevalence, pre-disposing factors to and impact of violent relationships within the home } \\
\text { (Peckover, 2002a) } \\
\text { - } \quad \text { Knowing about the dangers of domestic violence for child and family well-being (Bacchus et al., 2003) } \\
\text { Knowing that health visitors can have a pivotal role in helping families where there is domestic violence } \\
\text { (Bacchus et al.,2003) }\end{array}$ \\
\hline $\begin{array}{l}\text { Universal } \\
\text { Partnership } \\
\text { Plus : skills }\end{array}$ & $\begin{array}{l}\text { - Identification of complex health needs through on-going health needs assessment (Appleton and Cowley, } \\
\text { 2008a; Barlow et al., 2010; Davis et al., 2007) } \\
\text { Engagement, active listening, questioning, challenging, agenda setting, re-focusing and closing (Barlow, } \\
\text { Davis et al., 2007) } \\
\text { - } \text { Building trust with vulnerable families through honest communication and displaying professional } \\
\text { characteristics such as empathy, respect for the family's efforts to change, professional humility in the face } \\
\text { of the family's efforts to succeed, optimism and realism (Davis et al., 2005, Davis, Day et al., 2007) } \\
\text { - Being dependable } \\
\text { - Partnership working : involving families in the decision making process (Barlow et al., 2010; Davis et al., } \\
\text { 2005) } \\
\text { Not giving up on families even when other agencies have done so (Chalmers 1992) }\end{array}$ \\
\hline $\begin{array}{l}\text { Universal } \\
\text { Partnership } \\
\text { Plus : abilities }\end{array}$ & $\begin{array}{l}\text { - } \quad \text { To respect families efforts to change (Davis et al., 2005) } \\
\text { - } \quad \text { To empathise with families in their unique situations (Davis et al., 2005) } \\
\text { - } \quad \text { To form trusting relationships (Davis and Tsianis, 2005; Puura et al., 2005) } \\
\text { - To manage workload, to enable frequent home based contact according to needs of vulnerable families, } \\
\text { with at least one contact antenatally (Davis and Tsianis, 2005; Puura et al., 2005; Kemp et al., 2011) }\end{array}$ \\
\hline
\end{tabular}




\begin{tabular}{|c|c|c|c|}
\hline Community & Universal & $\begin{array}{l}\text { Universal } \\
\text { Plus }\end{array}$ & $\begin{array}{l}\text { Universal } \\
\text { Partnership Plus }\end{array}$ \\
\hline 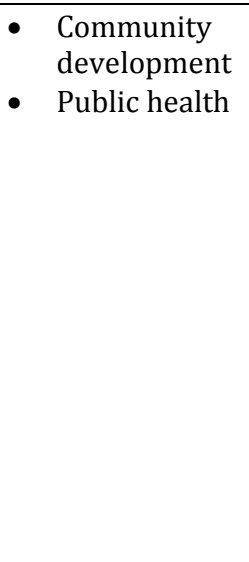 & $\begin{array}{ll}\text { - } & \text { Breastfeeding } \\
\text { - } & \text { Accidents/unintentional } \\
& \text { injury } \\
\text { - Immunisation } \\
\text { - Involving fathers }\end{array}$ & $\begin{array}{ll}- & \text { Nutrition } \\
& \text { and obesity } \\
& \text { prevention } \\
\text { - } & \text { Parenting } \\
\text { - } & \text { Perinatal } \\
\text { mental } & \text { health } \\
\text { including } \\
\text { post-natal } \\
\text { depression }\end{array}$ & $\begin{array}{ll}\text { - } & \text { Domestic } \\
\text { violence and } \\
\text { abuse } \\
\text { Early } \\
\text { intervention } \\
\text { programmes } \\
\text { - Seldom-heard } \\
\text { groups, } \\
\text { including black } \\
\text { and minority } \\
\text { ethnic groups } \\
\text { Homeless } \\
\text { people, } \\
\text { travelling } \\
\text { community }\end{array}$ \\
\hline
\end{tabular}




\section{Highlights}

- An aspirational 'orientation to practice' underpins all health visitors' work

- Practice focuses on home visiting, forming relationships and needs assessments

- Health visitors' knowledge, skills and abilities are central to effective practice

- The large amount of the learning needed is not well covered by current preparation

- A radical re-think of health visitor education is needed to accommodate the depth and breadth of knowledge skills and abilities required for practice 